\title{
The Changing Value of Seniority in the U.S. House: Conditional Party Government Revised
}

\section{Citation}

Hall, Andrew B., and Kenneth A. Shepsle. 2014. "The Changing Value of Seniority in the U.S. House: Conditional Party Government Revised." The Journal of Politics 76 (1) (January): 98-113. doi:10.1017/s0022381613001102.

\section{Published Version}

doi:10.1017/S0022381613001102

\section{Permanent link}

http://nrs.harvard.edu/urn-3:HUL.InstRepos:34203792

\section{Terms of Use}

This article was downloaded from Harvard University's DASH repository, and is made available under the terms and conditions applicable to Open Access Policy Articles, as set forth at http:// nrs.harvard.edu/urn-3:HUL.InstRepos:dash.current.terms-of-use\#OAP

\section{Share Your Story}

The Harvard community has made this article openly available.

Please share how this access benefits you. Submit a story.

\section{Accessibility}




\title{
The Changing Value of Seniority in the US House: Conditional Party Government Revised*
}

\author{
Andrew B. Hall ${ }^{\dagger} \quad$ Kenneth A. Shepsle $^{\ddagger}$
}

February 19, 2012

Note to the reader: Additional statistical information, robustness checks, and a description of the data are available in the Supporting Information, which will be available in an online appendix before publication.

\footnotetext{
${ }^{*}$ For comments and advice we would like to thank the participants in the Political Economy Workshop, the American Politics Workshop, and the Graduate Student Political Economy Workshop, all of Harvard University, as well as the following individuals: John Aldrich, James Alt, Morris Fiorina, Jeffry Frieden, John Marshall, Mathew McCubbins, David Mayhew, Paul Peterson, Sean Theriault, Dustin Tingley, Stanley Veuger, Joachim Wehner, and especially Anthony Fowler and James Snyder.

${ }^{\dagger}$ PhD Student, Harvard University Department of Government. hall@fas.harvard.edu

${ }^{\ddagger}$ George D. Markham Professor of Government, Harvard University. kshepsle@iq.harvard.edu
} 


\begin{abstract}
In this paper we argue that institutional changes to the seniority system have electoral consequences to incumbents. Building on the theory of Conditional Party Government, we argue that the consolidation of power in the hands of party leadership reduces the electoral value of seniority. This reduction occurs because power that was previously in the hands of committee chairs, whose roles are obtained through seniority, is ceded to party leaders. We present empirical evidence supporting this argument. Our findings suggest that the "condition" of Conditional Party Government, i.e. preference homogeneity among the majority party, is only a necessary condition; in order for centralization to occur, party reformers must also overcome the opposition of entrenched senior members. The empirical results suggest that studies of electoral outcomes should include institutional variables in their statistical models, and that studies of legislative institutions should consider electoral consequences when modeling rule changes made by legislators.
\end{abstract}

Word count: 8,058 
Partly in response to the famous interrogative of Krehbiel (1993) - "Where's the party?" - a number of scholars have proposed arguments in which legislative parties play a consequential role in chamber politics. ${ }^{1}$ The cartel theory associated with Cox and McCubbins (2007) and the conditional party government theory of Aldrich and Rohde (2001) share the view that parties influence legislative outcomes through leadership control of institutional arrangements and practices. That majority leadership impact on legislature proceedings is variable is made especially explicit in the Aldrich-Rohde theory of conditional party government ( $\mathrm{CPG}$, hereafter).

The "condition" part of CPG theory is the degree of homogeneity of policy preferences among members of the majority party and, a frequent accompaniment, the degree of polarization between it and the opposition. ${ }^{2}$ When the majority party coheres around policy, its members "grease the skids" for the prosecution of the party's policy agenda by delegating agenda-setting authority and other powers and resources to their party leaders. In general, that is, "there is a relationship between chamber CPG and the internal organization of the chamber" (Aldrich, Berger, and Rohde, 2002: 32) or, more concretely, "the greater the degree to which the condition [preference homogeneity within and preference divergence between legislative parties] is met, the more likely that members of a party choose to provide their legislative party institutions and party leadership with stronger powers and greater resources" (Aldrich, Rohde, and Tofias, 2007: 103). Majority party success in passing commonly supported legislation burnishes the party label and underscores the record of accomplishment of its members. These are assets when majority legislators next face their constituents for contract renewal.

The policy preferences of members of the majority party, however, may be heterogeneous think the north-south split in the 1940s, 1950s, and early 1960s in Sam Rayburn's Democratic majority (lingering on the rest of the 60s and into the 1970s under McCormack and Albert) or the Tea Party-mainstream conservative split afflicting John Boehner's Republican majority more recently. In circumstances such as these, majority-party members are loathe to entrust their leaders with unchecked discretion. Instead, leaders are made beholden to their caucuses and to their far-

\footnotetext{
${ }^{1}$ This literature is summarized by Cox and McCubbins (2005, Chap. 1; 2007).

${ }^{2}$ The CPG literature has not focused much on the extent of preference homogeneity among members of the opposition party. Perhaps this is because homogeneity in either party is a function of sorting in the electorate (along with reinforcing redistricting), so that homogeneity in one is often accompanied by homogeneity in the other. We will devote most of our attention, as does the CPG literature, to the state of the majority party. However, our argument suggests some interesting distinctions of CPG's effect on the majority and minority parties that we examine in the next section.
} 
from-reliable, indeed sometimes irreconcilable, powerful senior colleagues - committee chairs for Rayburn, factional leaders for Boehner - and have few tools with which to broker consensus.

As a theoretical expectation of CPG theory, then, we should see incumbents of the majority party (and perhaps the minority party) keen to strengthen party organization and institutional authority in eras when the "condition" is satisfied, and to decentralize authority in eras when the "condition" fails. Moreover, we should see incumbents of the majority party benefitting electorally from these moves in periods in which the condition is met. That is, we should see stronger electoral advantage for majority-party incumbents in an era of centralized party government. We provide evidence supporting this view.

But that is not the end of the story. In a strong-party era - one in which central party institutions and leadership have been strengthened - we uncover a differential effect on electoral benefits among members of the majority party. In an era of weak party leadership, there is electoral benefit to seniority. Because senior members dominate committee and party institutions, they are valuable to their districts and electorally successful as a result. ${ }^{3}$ The value of seniority, however, declines in a strong-party era in which, with central party leaders calling the shots, majority-party members are effectively foot soldiers for, e.g., Newt Gingrich or Nancy Pelosi. That is, while there is a clear upside for majority-party members in a strong-party era from facilitating the prosecution of their party's agenda, the costs of strengthening party institutions are unevenly borne by its members, afflicting senior members more significantly than junior members. This is our novel revision of CPG theory, and it, too, is revealed quite clearly in our empirical analysis. Moreover, this diminishing advantage of seniority in strong-party eras relative to weak-party eras is exclusively a majorityparty affair. No such tax on political capital (seniority) is exacted from members of the minority party.

These and other empirical expectations are examined in the next section. There we describe a dataset comprising congressional elections from 1946 to 2008 enabling us to analyze a modified version of CPG theory. We demonstrate that majority-party leaders endowed with enhanced agenda power and other institutional authority benefit the majority party rank-and-file, but at the partial

\footnotetext{
${ }^{3}$ This assessment is at the heart of a remarkable paper by McKelvey and Riezman (1992), demonstrating that the endogenous creation of a seniority system induces an incumbency advantage - that constituencies, anticipating a seniority system in the next legislative session, will be inclined to re-elect their own incumbent so as not to lose their district's "place in the seniority queue." Seniority attributes, moreover, raise the bar for a successful challenge, thus discouraging quality challengers from contesting these seats (Jacobson, 1989).
} 
expense of seniors in the majority party. Majority party members may exhibit consensus on policy, but nevertheless benefit differentially from making the institutional moves to capture the fruits of this consensus.

Our argument should be seen as fitting into a literature connecting the electoral and legislative arenas. Too frequently those forecasting congressional elections fail to take on board the impact of legislative arrangements and political behavior therein. Legislative elections are not dependent exclusively on national conditions and presidential popularity on election day, but also pivot on how legislators have conducted themselves, as legislators, in the previous legislative session (see for example Brady, Fiorina, and Wilkins, 2011). And, in light of this, legislators - especially majority legislators - arrange institutional practices with a gimlet eye on future electoral contests, a perspective that goes back to Mayhew (1974), Fiorina (1977, 1989), and their intellectual progeny.

\section{Empirical Strategy and Data}

Our goal is to examine the returns to seniority across eras of strong and weak legislative parties. Our claim is that times of stronger parties should correspond to lower returns to seniority for majority-party incumbents. To test this claim, we exploit the reforms of the 1970s in the House of Representatives which, we argue, partition the postwar period into the "Weak Party Era" (19461976) and the "Strong Party Era" (1977-present).

Due to many factors including an increase in party homogeneity, both parties undertook a series of rule changes in the early 1970s that augmented the power of the party leadership at the expense of senior members. The majority Democrats in particular assaulted the tradition of deference to seniority in assigning committee chairmanships. No longer would plum committee chairmanships belong exclusively to senior members by right; instead, increasing discretion over committee chairmanships would devolve upon the party caucus and party leadership. The majority Democrats (and later the majority Republicans) strengthened the party leadership, particularly its control of the Rules Committee, plenary time, committee assignments, and bill referral.

Shaw (1981: 274) captures the changes clearly: "In various ways traditional norms of deference were giving way to new arrangements designed to involve junior representatives and senators in matters previously the concern of senior members." Discussing these changes to the committee 
chairmanship selection process, Democratic Speaker of the House Carl Albert declared: "The seniority system - for sixty-two years the path to legislative domination - died that day...From that moment on every chairman knew that power flowed not from personal longevity but from the entire Democratic membership" (as quoted in Remini 2006: 433). The upshot of the reforms was a stark shift from an era of weak legislative parties, in which committee agenda power and deference to seniority loomed large, to an era of strong parties, in which party leadership held a far tighter grip on the reins. ${ }^{4}$

We take advantage of this historical change by comparing the electoral performance of incumbents of differing levels of seniority in the Weak Party Era (WPE) and the Strong Party Era (SPE). Our main prediction, which we test below, is that seniority is more valuable electorally in the Weak Party Era, when senior members are able to convert their longevity into more value for their constituents. Because the reforms steadily accumulated through the mid-1970s (Shaw 1981), we take 1976 to be the last election considered part of the Weak Party Era. However, all of the results we report are robust to moving the end of the Weak Party Era backwards or forwards in time (see details in the robustness section below).

\section{Data and a First Look}

To test our argument, we use a dataset on congressional elections from 1946-2008 that comes from a series of papers including Ansolabehere et. al. (2010) and Hirano et. al (2010). ${ }^{5}$ It identifies representatives by name, district, and year, and contains vote totals for all candidates. Because we have representatives' names, we are able to track them over time to determine their seniority, avoiding problems from redistricting.

Our argument highlights a key shift occurring around 1976 in which seniority began to matter less within Congress. Since voters care about the value of a representative to the district, we expect that institutional changes within Congress in the 1970s, reducing the advantages enjoyed by (and hence the value of) more senior members, have "taxed" those members' vote shares. These institutional changes were not exogenous, but rather were brought about by strategic actors who

\footnotetext{
${ }^{4}$ Because the Democratic Party was the majority party in the Strong Party Era until 1995, most of the relevant action occurred in the Democratic Caucus. Of course, in 1995 the Republicans dramatically centralized control in their leadership.

${ }^{5}$ The dataset was generously provided to the authors by James Snyder.
} 
valued the increased efficiency that a more centralized party offered. The rule changes thus traded away some of the advantages of more senior members for a party-brand advantage enjoyed by all members of the party.

We expect the distribution of majority-party incumbent vote shares to have changed from the Weak Party Era to the Strong Party Era in two respects. First, a mean shift is expected, reflecting the net benefit to all members of the newly strengthened party. Second, we expect a concentration (variance reduction) in the distribution reflecting the fact that junior and senior members have become more interchangeable as seniority matters less. ${ }^{6}$ More formally, our null hypotheses are:

$$
\begin{aligned}
& H_{O, \mu}: \mu_{W P E}=\mu_{S P E} \\
& H_{o, \sigma}: \sigma_{W P E}^{2}=\sigma_{S P E}^{2}
\end{aligned}
$$

A one-sided means test rejects the null hypothesis that the means are the same in the two eras against the alternate hypothesis that $\mu_{S P E}>\mu_{W P E}$ with p-value $<.0001$. A one-sided equalityof-variance test rejects the null hypothesis that the variances are the same against the alternative hypothesis that $\sigma_{W P E}^{2}>\sigma_{S P E}^{2}$ with p-value $<.0006 .{ }^{7}$ We therefore find strong evidence for our hypotheses about the changing distributions of majority-party incumbent vote share. Figure 1 is consistent with both the shift and the concentration predictions: the distribution of majority-party incumbent vote share has shifted to the right in the SPE, and it has become more concentrated (i.e. lower variance).

\section{Empirical Results}

In Table 1 we present our main OLS results. Our dependent variable is the two-party vote share, measured in percentage points (i.e. ranging from 0 to 100), for all majority-party incumbent representatives running for contested reelection in the House from 1946 to $2008 .^{8}$ The variable SPE (Strong Party Era) is a dummy variable equaling one for all years after 1976.

\footnotetext{
${ }^{6}$ We operationalize vote share as the share of the two-party vote for each majority-party incumbent candidate. ${ }^{7}$ For the $t$-test, we use Welch's test to account for unequal variance (done using ttest with the unequal option in Stata), although our results are robust to other forms of the test. To test for unequal variance, we use Levene's test (using the command sdtest in Stata), but our results are robust to using Bartlett's test as well (using the command oneway in Stata).

${ }^{8}$ In the Supporting Information, we present probit results using electoral victory as the binary dependent variable. Results are consistent with the regressions presented below.
} 


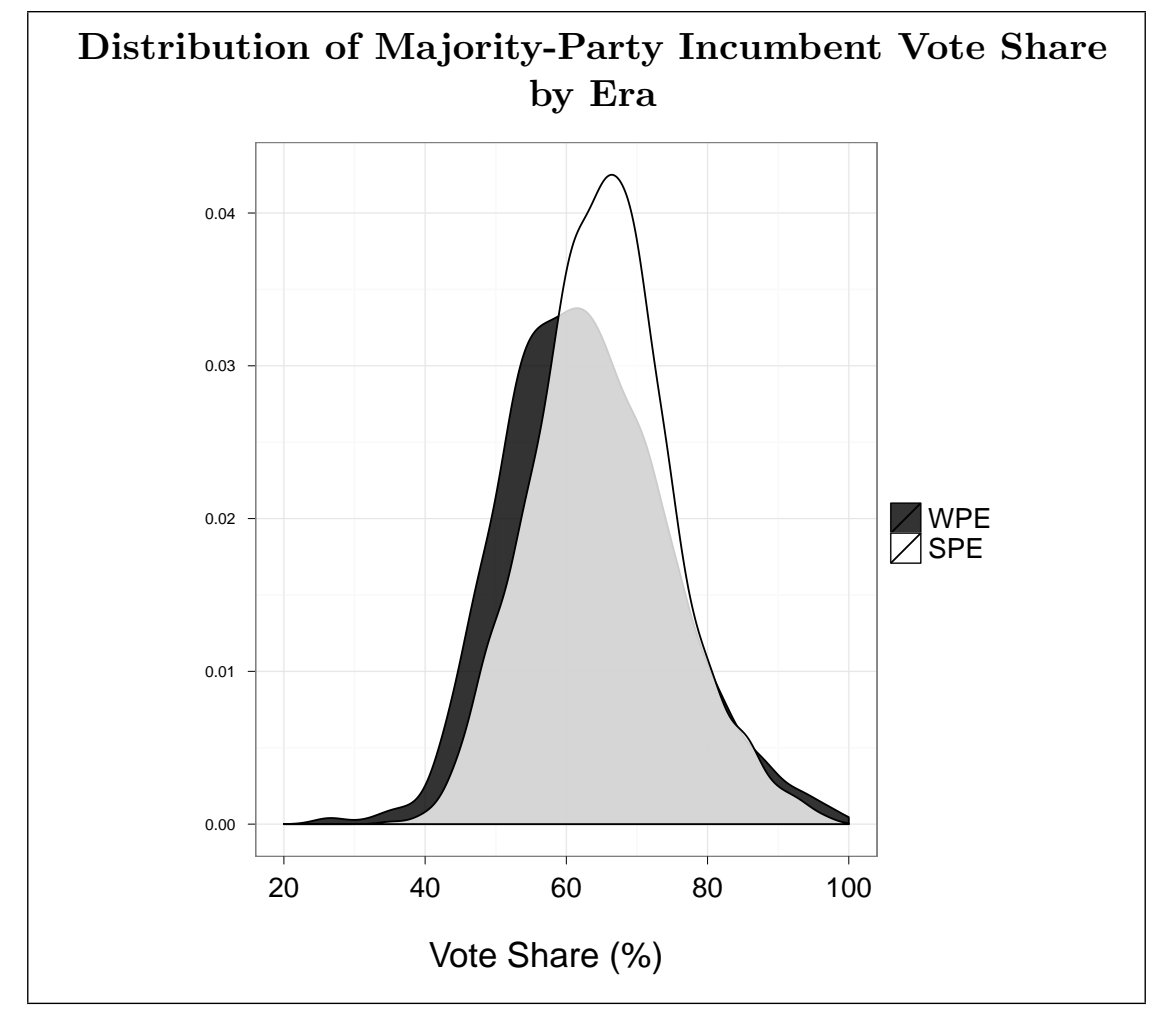

Figure 1 - In this figure we plot the density of majority-party incumbent vote share in the WPE (1946-1976), drawn in black, and in the SPE (1977-2008), drawn in white. The graph shows that majority-party incumbent vote share has shifted to the right in the SPE, representing a common benefit to all majority-party incumbents, and has also condensed, representing an increase in the similarity of majority-party incumbents.

We measure seniority as the number of previous times an incumbent has won reelection. For example, a two-term representative has a seniority value of 1 , since she has successfully run one previous time as an incumbent. ${ }^{9}$ To address autocorrelation among repeated observations of the same incumbent, we cluster all standard errors by representative.

Column (1) corresponds to the following model:

$$
Y_{i t}=\alpha+\alpha_{S P E} S P E_{i t}+\beta_{S} S_{i t}+\beta_{S P E}\left(S_{i t} \cdot S P E_{i t}\right)+\epsilon_{i t}
$$

Here $i t$ indexes representative-year observations (note that we are pooling over $t$ ), $\epsilon_{i t} \sim N\left(0, \sigma_{i}^{2}\right)$, $S$ is our measure of seniority, and $Y$ is vote share. This directly tests our hypothesis that the returns

${ }^{9}$ This definition may seem odd, but it allows for an easier interpretation of the constant term. Since we are only using incumbents, every observed representative has served at least one term in Congress. We are merely taking the number of terms a representative has served and shifting back by one. The constant therefore represents the mean vote share for an incumbent running for her first reelection. 


\begin{tabular}{|c|c|c|}
\hline \multicolumn{3}{|c|}{$\begin{array}{c}\text { Majority-Party Incumbent Vote Share and Seniority } \\
\text { Across Eras, 1946-2008 }\end{array}$} \\
\hline VARIABLES & $\begin{array}{c}\text { OLS } \\
(1) \\
\text { Vote Share }\end{array}$ & $\begin{array}{c}\text { Rep Fixed Effects } \\
(2) \\
\text { Vote Share }\end{array}$ \\
\hline $\operatorname{SPE}\left(\hat{\alpha}_{S P E}\right)$ & $\begin{array}{l}5.51^{*} \\
(0.64)\end{array}$ & $\begin{array}{c}0.71 \\
(0.85)\end{array}$ \\
\hline Seniority $\left(\hat{\beta}_{S}\right)$ & $\begin{array}{l}0.83^{*} \\
(0.08)\end{array}$ & $\begin{array}{l}0.57^{*} \\
(0.10)\end{array}$ \\
\hline Seniority $\cdot \operatorname{SPE}\left(\hat{\beta}_{S P E}\right)$ & $\begin{array}{l}-0.61^{*} \\
(0.11)\end{array}$ & $\begin{array}{l}-0.65^{*} \\
(0.12)\end{array}$ \\
\hline Constant $(\hat{\alpha})$ & $\begin{array}{l}60.84^{*} \\
(0.46)\end{array}$ & $\begin{array}{l}64.47^{*} \\
(0.46)\end{array}$ \\
\hline Observations & 5,940 & 5,940 \\
\hline R-squared & 0.05 & 0.02 \\
\hline Number of Fixed Effects & & 1,842 \\
\hline
\end{tabular}

Table 1 - In this table we present our main results. In column (1), we regress vote share on seniority for majority-party incumbents, along with a dummy indicating the SPE (1977-2008), and an interaction of this dummy and seniority. The results show that seniority provides a high return in the WPE (1946-1976), but a much lower return in the SPE. In column (2), we use fixed effects for individual representatives and find a similar result.

to seniority should be lower in the Strong Party Era. $\beta_{S P E}$ represents the additional vote share associated with an increase of one in seniority in the Strong Party Era. The overall increase in vote share associated with an increase of one term of service in the Strong Party Era is therefore $\beta_{S}+\beta_{S P E}$. Since we are interested in whether the return to seniority changes in the Strong Party Era, relative to the Weak Party Era, we focus on the sign and the significance level of $\hat{\beta}_{S P E}$.

The regression results are consistent with our hypothesis. While an additional term of seniority in the Weak Party Era is associated with a .83 percentage point increase in incumbent vote share, an additional term in the Strong Party Era is associated with only a .22 percentage point increase, a difference that is statistically significant at the .01 level. ${ }^{10}$

To illustrate, a freshman member of the majority party (an incumbent who has never run as an incumbent so that $S=0)$ can expect a vote share in the Strong Party Era of $66.35 \%(60.84 \%+$ $5.51 \%$ ), whereas she can expect only $60.84 \%$ in the Weak Party Era - an SPE premium of 5.51\%. The ability of her party to prosecute its agenda in the Strong Party Era burnishes the party label

\footnotetext{
${ }^{10}$ Note that all majority-party incumbents enjoy a boost of $5.51 \%$ in vote share in the SPE, independent of seniority - the dividend of a more effective majority party.
} 
and provides a dividend - indeed, a non-trivial dividend. As seniority accumulates, a member's expected vote share grows, but the size of the SPE dividend shrinks and ultimately turns negative. Thus, a four-term member $(S=3)$ expects a $67.01 \%$ vote share in the Strong Party Era $(60.84 \%$ $+5.51 \%+3(0.22 \%))$ and $63.33 \%$ in the weak party era $(60.84 \%+3(0.83 \%))$, yielding an SPE dividend of $3.68 \%$. Compared to the freshman, a four-term member expects a larger vote share (67.01\% v. $66.35 \%)$ but a smaller dividend (3.68\% v. 5.51\%) in the Strong Party Era. An eleventerm member $(S=10)$ in the Strong Party Era expects a vote share of $68.55 \%$ compared to $69.14 \%$ in the Weak Party Era - a negative dividend of $-0.69 \%$. The value of seniority in the Weak Party Era, when large enough, exceeds the value of being a senior member of a strong majority party. This pattern of results requires a reinterpretation of conditional party government, something we develop further in the discussion section.

In column (2), we add fixed effects for individual representatives. This strategy controls for unobserved differences across representatives. The results show that even within a given majorityparty incumbent's career, the switch to the new party regime is associated with a significant reduction in the return to seniority. ${ }^{11}$

In the above regressions we use majority-party incumbent vote shares in contested elections. We are not including incumbents who run unopposed, or who choose not to run. ${ }^{12}$ It is well known that these factors trouble many estimates of incumbency advantage (see for example Gelman and King, 1990). However, because we are looking at the difference between two eras, these omissions should not affect our result. It is not our goal to estimate the incumbency advantage, but rather to show that, among incumbents, the returns to seniority have diminished in the Strong Party Era.

In our main specification, we employ a linear model as a good first approximation of the return to seniority. It is reasonable, however, to suspect that the relationship between seniority and vote share is non-linear, with gains to seniority accruing faster in earlier terms. A sophomore legislator might see her vote share increase markedly in her second reelection attempt compared to her first, but it is unlikely that John Dingell gains significant vote share between, say, his 25th and 26th terms of service. Alford and Hibbing (1981) provide evidence for this form of relationship. With

\footnotetext{
${ }^{11}$ It is worth noting that, while the coefficients appear to suggest that the seniority effect here, $\hat{\beta}_{S}+\hat{\beta}_{S P E}$, has gone negative, this sum is not significantly different from zero $(p=.35)$. The attenuation of $\hat{\alpha}_{S P E}$ in the fixed-effects model likely results from only estimating it using members whose careers span the two eras.

${ }^{12}$ Our results are robust to the inclusion of uncontested elections, where incumbents are coded as receiving $100 \%$ of the vote share.
} 
the advantage of 27 additional years of data, we are able to confirm this non-linearity and compare returns across our two eras.

In Figure 2, we employ a generalized additive model (GAM), the widely-used scatter-plot smoothing method proposed in Hastie and Tibshirani (1990), to show the graphical relationship between seniority and vote share in the WPE and the SPE. This method does not impose a parametric model, allowing the data to define the relationship between seniority and vote share.

In each graph we plot the expected vote share for majority-party incumbents conditional on seniority, as calculated by the model. The return to seniority is the slope of the line in each graph. We see that the WPE has a steeper slope than the SPE - evidence that the value of seniority was higher when committees, rather than parties, possessed agenda power. At lower levels of seniority, the conditional mean of vote share has been pulled up in the SPE. For example, first-time incumbents in the WPE are predicted to receive about $59 \%$ of the two-party vote in this model, while first-time incumbents in the SPE are predicted to receive $65 \%$. This shift represents the dividend resulting from centralizing power. The graphs make our argument clear: while there has been a dividend to all party members, it has disproportionately benefited more junior members.
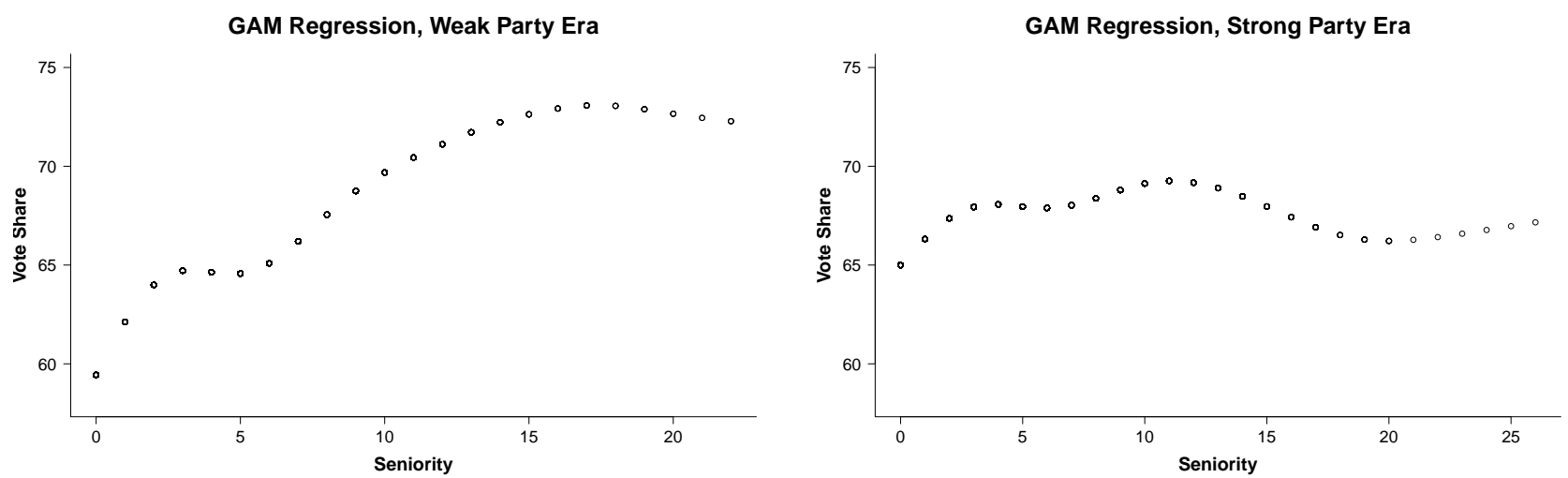

Figure 2 - In the above figures we use non-parametric scatter plot smoothing to show the positive, non-linear association between seniority and majority-party incumbent vote share in the WPE, and the relatively flat, attenuated association between the two variables in the SPE. Each point on the graph represents the GAM estimate for the average majority-party incumbent vote share, conditional on the level of seniority.

In the OLS and fixed-effects analyses of Table 1, we include all fifty states in our sample. The one-party nature of the South in the Weak Party Era could bias our results. During the WPE southern Democratic incumbents received extremely high vote shares and were very senior on average. The SPE coincides with many changes in the political landscape, including the effects 
of the Voting Rights Act of 1965. If the ultimate effect of the Voting Rights Act were harm to southern Democratic incumbents' vote shares, the decline in the importance of seniority we observe more generally could be driven by the southern states rather than by our proposed explanation. Alternatively, our finding could stem from safe southern Democratic districts in the WPE turning into safe Republican districts in the SPE. Because the majority party in our study is almost always the Democratic party, our results could come from ignoring southern incumbents in the SPE. To address these and other possible concerns about the southern states, we re-run the analysis from Table 1 using only northern states. As seen in Table 2, our result is stronger when restricted to northern incumbents.

\begin{tabular}{|c|c|c|}
\hline \multicolumn{3}{|c|}{$\begin{array}{l}\text { Northern Majority-Party Incumbent Vote Share and } \\
\text { Seniority Across Eras, 1946-2008 }\end{array}$} \\
\hline VARIABLES & $\begin{array}{c}\text { OLS } \\
(3) \\
\text { Vote Share }\end{array}$ & $\begin{array}{c}\text { Rep Fixed Effects } \\
(4) \\
\text { Vote Share }\end{array}$ \\
\hline $\operatorname{SPE}\left(\hat{\alpha}_{S P E}\right)$ & $\begin{array}{l}7.04^{*} \\
(0.77)\end{array}$ & $\begin{array}{c}0.76 \\
(0.99)\end{array}$ \\
\hline Seniority $\left(\hat{\beta}_{S}\right)$ & $\begin{array}{l}1.01^{*} \\
(0.10)\end{array}$ & $\begin{array}{l}0.93^{*} \\
(0.09)\end{array}$ \\
\hline Seniority $\cdot \operatorname{SPE}\left(\hat{\beta}_{S P E}\right)$ & $\begin{array}{l}-0.79^{*} \\
(0.13)\end{array}$ & $\begin{array}{l}-0.89^{*} \\
(0.13)\end{array}$ \\
\hline Constant $(\hat{\alpha})$ & $\begin{array}{l}58.86^{*} \\
(0.51)\end{array}$ & $\begin{array}{l}62.55^{*} \\
(0.47)\end{array}$ \\
\hline Observations & 3,981 & 3,981 \\
\hline R-squared & 0.08 & 0.05 \\
\hline Number of Fixed Effects & & 1,227 \\
\hline
\end{tabular}

Table 2 - In this table we reproduce our main results, restricting the sample to only non-southern states. In column (3), we regress vote share on seniority for majority-party incumbents, along with a dummy indicating the SPE (1977-2008), and an interaction of this dummy and seniority. The results show that seniority provides a high return in the WPE (1946-1976), but a much lower return in the SPE. In column (4), we use fixed effects for individual representatives and find a similar result.

\section{Trends in the Returns to Seniority}

We have presented evidence that the average return to seniority for majority-party incumbents is lower in the Strong Party Era than in the Weak Party Era. In this subsection, we address two 
concerns about our empirical strategy: we show that our finding is not the result of one or two strange elections, and that it is not caused by a trend in voting behavior over time.

In Figure 3, we report the results of a cross-sectional regression of vote share on seniority for each year in our dataset. Specifically, for each year we run the regression $Y_{i}=\alpha+\gamma S_{i}$ and plot the estimate $\hat{\gamma}$. The figure shows that all but two years in the Weak Party Era exhibit returns to seniority higher than the Strong Party Era mean. It confirms that the difference in the average return to seniority between the two eras, which $\hat{\beta}_{S P E}$ measures in earlier tables, is not the result of one or two negative shocks but is instead a relatively consistent change.

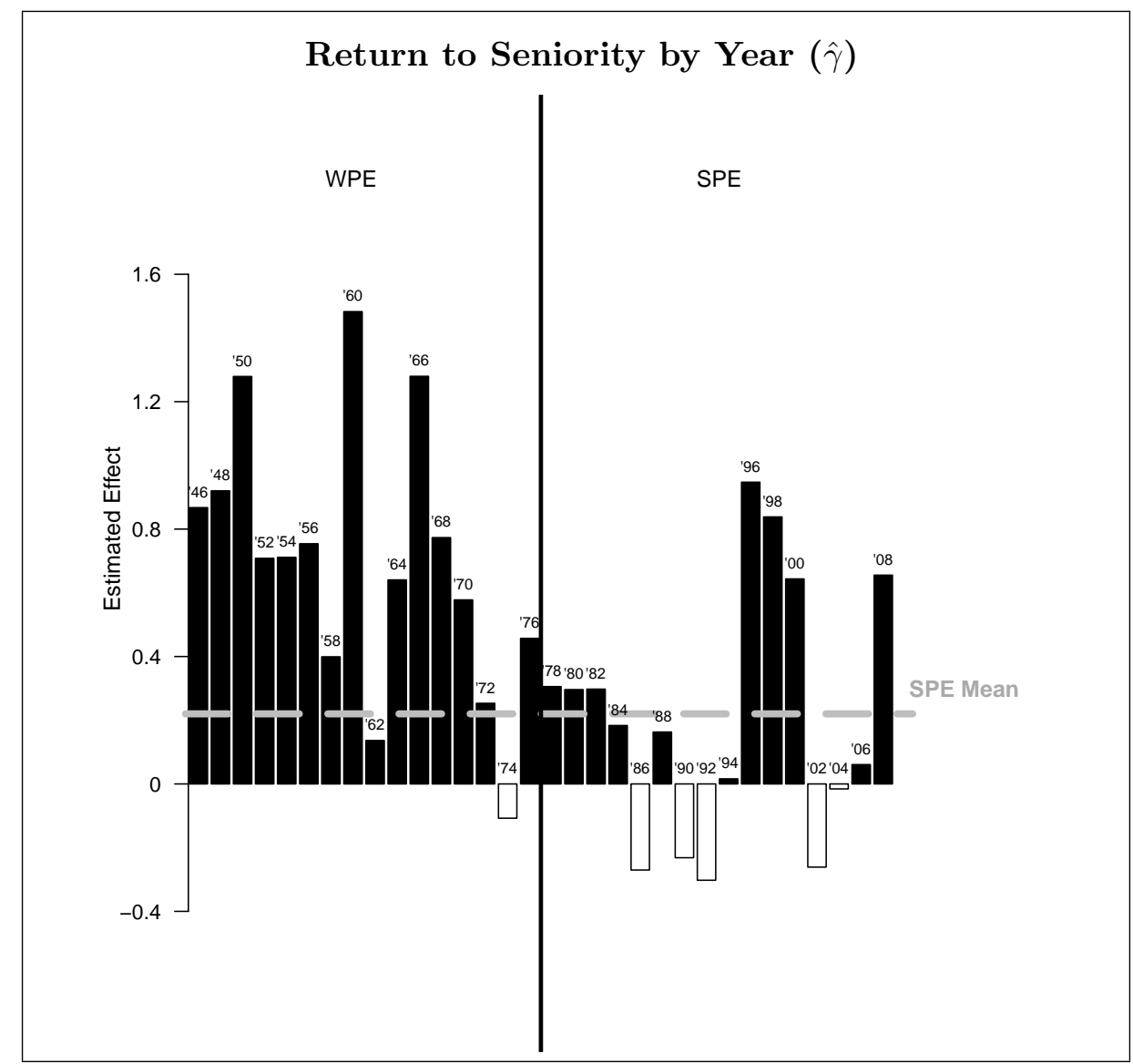

Figure 3 - In this figure, we graph the return to seniority by year. Each bar represents $\hat{\gamma}$ in a regression $Y_{i}=\alpha+\gamma S_{i}$ for year $t$, i.e. a cross-section regression of vote share on seniority in a single congress. The results suggest a persistent decrease in the returns to seniority in the SPE: only two years in the WPE exhibit returns to seniority at or below the mean return for years in the SPE.

Another concern with our measure of the change in the average return to seniority is that we might be picking up a trend in voter behavior. If voters are becoming more "anti-seniority" over time, for example, we might observe a decrease in the returns to seniority that is unrelated to 
institutional factors. ${ }^{13}$ To address this issue, we replicate Table 1 using the minority party instead of the majority party. The results in Table 3 show that there is no decrease from the WPE to the SPE in the average return to seniority for the minority party, i.e. $\hat{\beta}_{S P E}$ is not negative. This table provides compelling evidence that voters are not simply becoming more anti-seniority over time. (Indeed, the average minority incumbent's seniority contributed positively to vote share in the SPE.)

\begin{tabular}{|lcc|}
\hline \multicolumn{3}{|c|}{ Minority-Party Incumbent Vote Share and Seniority } \\
Across Eras, 1946-2008 \\
& All States & North \\
& $(7)$ & $(8)$ \\
VARIABLES & Vote Share & Vote Share \\
\hline & & \\
SPE $\left(\hat{\alpha}_{S P E}\right)$ & $4.96^{*}$ & $5.24^{*}$ \\
& $(0.67)$ & $(0.81)$ \\
Seniority $\left(\hat{\beta}_{S}\right)$ & 0.17 & 0.12 \\
& $(0.09)$ & $(0.10)$ \\
Seniority $\cdot$ SPE $\left(\hat{\beta}_{S P E}\right)$ & 0.19 & 0.29 \\
& $(0.13)$ & $(0.15)$ \\
Constant $(\hat{\alpha})$ & $62.31^{*}$ & $62.00^{*}$ \\
& $(0.45)$ & $(0.52)$ \\
& & \\
Observations & 4,743 & 3,571 \\
R-squared & 0.07 & 0.08 \\
\hline Standard errors (clustered by representative) & in parentheses \\
& $* p<0.05$ & \\
\hline
\end{tabular}

Table 3 - In this table we rerun our main specification (from Table 1) restricting the sample to minority-party incumbents. In column (7) we include all states, and in column (8) we exclude the southern states. In both cases, we find no reduction in returns to seniority for the minority party.

\section{Polarization as an Alternative Explanation}

Because of the necessarily crude nature of our analysis - comparing returns across two time periods - we can never precisely identify either the change in the returns to seniority or the change in the average majority-party incumbent vote share caused by the congressional reforms of the 1970s. However, we can marshall evidence suggesting that our story is more consistent with the data than are alternative explanations.

Consider the case of polarization. A significant body of work in political science examines the growing polarization of American politics (see for example McCarty et. al., 2006). Much of the

\footnotetext{
13 "Anti-seniority" could be reflected in complaints about so-called "career politicians."
} 
evidence we have presented so far may also seem consistent with an increase in partisan polarization. Increased polarization leads to more partisan voting behavior. Voting on a wholly partisan basis reduces the returns to seniority; as polarization increases, voters attach more weight to party label than to other characteristics such as seniority, specific policy goals, or even candidate quality.

Polarization and its electoral consequences will affect both parties. If polarization explains the majority party's reduction in the returns to seniority, we should see the same phenomenon in the minority party. However, as Table 3 showed, returns to seniority for the minority party, positive in the WPE, do not attenuate in the SPE (and in fact increase, if anything).

Furthermore, polarization should affect all facets of American politics. If polarization drives our empirical findings, then we might expect to find the same reduction in the returns to seniority, and accompanying strong-party "bump," in other areas. In Table 4, we replicate our empirical strategy using the US state senates, state assembly houses, and the US Senate. Because the datasets for these three legislative bodies do not extend far enough back to generate accurate estimates for the seniority levels of 1940s legislators, we use legislator fixed effects in all three cases. The results are clearly at variance with those found above in our analysis of the US House of Representatives. Majority-party incumbent legislators in the states have seen somewhat positive mean-shifts in vote share since 1976, but have seen no real changes in the returns to seniority. The US Senate, which we might think is the best control case for the US House, sees a large decrease in average vote share and no change in the returns to seniority. ${ }^{14}$ Overall, the results seem to demand a House-specific explanation like the one we provide, rather than an explanation based on a macro political force like polarization, which we would expect to affect a wide range of institutions (an expectation unfulfilled).

\footnotetext{
${ }^{14}$ It is worth noting that institutional change in the US Senate undermining seniority was well underway in the 1950 s and 1960s. These include the decline in the apprenticeship norm and the adoption of the Johnson Rule (facilitating the appointment of junior senators to top committees). The increasing Senate workload, additionally, made it necessary to rely on junior members, another development occurring during mid-century decades before the so-called "strong party era" in the House. This is not to say that everything happened in the Senate before the SPE. For example, the election of committee chairs in the Senate, and the more equitable allocation of staff (S.Res. 60), occurred in the 1970s. For details, see Ornstein, Peabody, and Rohde (1977) and their updates in the the three subsequent editions of Congress Reconsidered.
} 


\begin{tabular}{|c|c|c|c|}
\hline \multicolumn{4}{|c|}{ Placebo Tests Using Other Chambers } \\
\hline VARIABLES & $\begin{array}{c}\text { State Houses } \\
\quad(1) \\
\text { Vote Share }\end{array}$ & $\begin{array}{c}\text { State Senates } \\
(2) \\
\text { Vote Share } \\
\end{array}$ & $\begin{array}{c}\text { US Senate } \\
(3) \\
\text { Vote Share }\end{array}$ \\
\hline $\operatorname{SPE}\left(\hat{\alpha}_{S P E}\right)$ & $\begin{array}{c}0.37 \\
(0.65)\end{array}$ & $\begin{array}{l}4.21^{*} \\
(1.27)\end{array}$ & $\begin{array}{l}-9.21^{*} \\
(3.42))\end{array}$ \\
\hline Seniority $\left(\hat{\beta}_{S}\right)$ & $\begin{array}{l}-0.23 \\
(0.23)\end{array}$ & $\begin{array}{l}-0.09 \\
(0.52)\end{array}$ & $\begin{array}{l}-1.13 \\
(1.15)\end{array}$ \\
\hline Seniority $\cdot \operatorname{SPE}\left(\hat{\beta}_{S P E}\right)$ & $\begin{array}{l}-0.05 \\
(0.24)\end{array}$ & $\begin{array}{l}-0.70 \\
(0.54)\end{array}$ & $\begin{array}{c}1.29 \\
(1.40)\end{array}$ \\
\hline Constant $(\hat{\alpha})$ & $\begin{array}{l}65.23^{*} \\
(0.50)\end{array}$ & $\begin{array}{l}62.91^{*} \\
(0.99)\end{array}$ & $\begin{array}{l}66.69^{*} \\
(1.64)\end{array}$ \\
\hline Observations & 20,630 & 5,754 & 427 \\
\hline R-squared & 0.00 & 0.02 & 0.06 \\
\hline Number of Fixed Effects & 9,872 & 3,096 & 254 \\
\hline Standard errors (cl & $\begin{array}{l}\text { ered by represe } \\
\quad * p<0.05\end{array}$ & tative) in pare & theses \\
\hline
\end{tabular}

Table 4 - In this table we replicate our main analysis on three other legislatures: US state assembly houses, US state senates, and the US Senate. We do not find a consistent result across these chambers, suggesting that our findings on the House are not the result of macro-level phenomena in the United States over the same time period.

\section{Minority Party and Returns to Seniority}

Because it is the majority party that can directly influence procedure and thereby affect the returns to seniority, we have largely restricted our analysis to majority-party incumbents. We can now investigate whether the returns to seniority are different for majority and minority members. In the Weak Party Era, we might expect that the returns to seniority by and large accrue to members of the majority party, since it is the majority party that controls the committees. In the Strong Party Era, when parties rather than committees hold power, we might expect seniority to matter less in both parties.

To investigate these hypotheses, we specify a new model which we estimate in Table 5:

$$
Y_{i t}=\gamma+\gamma_{M} M i n_{i t}+\gamma_{S} S_{i t}+\gamma_{S M}\left(\operatorname{Min}_{i t} \cdot S_{i t}\right)+\epsilon_{i t}
$$

Here Min is a dummy variable equaling one if the candidate is a member of the minority party. $\gamma_{S M}$ represents the return to seniority for members of the minority party, benchmarked against returns to seniority for members of the majority party. 


\begin{tabular}{|lccc|}
\hline \multicolumn{4}{c}{ Returns to Seniority in Majority and Minority Parties, 1946-2008 } \\
& All Years & $1946-1976$ & $1977-2008$ \\
& $(9)$ & $(10)$ & $(11)$ \\
VARIABLES & Vote Share & Vote Share & Vote Share \\
\hline & & & \\
Minority $\left(\hat{\gamma}_{M}\right)$ & 0.91 & $1.46^{*}$ & 0.92 \\
Seniority $\left(\hat{\gamma}_{S}\right)$ & $(0.47)$ & $(0.60)$ & $(0.65)$ \\
& $0.52^{*}$ & $0.83^{*}$ & $0.22^{*}$ \\
Seniority $\cdot$ Minority $\left(\hat{\gamma}_{S M}\right)$ & $(0.06)$ & $(0.08)$ & $(0.08)$ \\
& $-0.19^{*}$ & $-0.66^{*}$ & 0.14 \\
Constant $(\hat{\gamma})$ & $(0.08)$ & $(0.12)$ & $(0.11)$ \\
& $63.65^{*}$ & $60.84^{*}$ & $66.35^{*}$ \\
& $(0.33)$ & $(0.46)$ & $(0.45)$ \\
Observations & 10,683 & 5,242 & 5,441 \\
R-squared & 0.02 & 0.04 & 0.01 \\
\hline Standard errors (clustered by representative) in parentheses & & \\
\hline
\end{tabular}

Table 5 - In this table we regress vote share on a dummy variable for members of the minority party, along with our measure of seniority, and an interaction of the two. In column (9) we use the whole sample. In columns (10) and (11) we divide the sample into the WPE (1946-1976) and the SPE (1977-2008). The results show that seniority is more valuable in the majority party during the WPE, but roughly equal across the parties in the SPE.

In column (9), we use the entire sample. The results show, as expected, that returns to seniority are higher for members of the majority party. In columns (10) and (11), we split the sample into the Weak Party Era and the Strong Party Era. ${ }^{15}$ Column (10) shows that there is a clear difference between the parties in returns to seniority in the Weak Party Era. Minority party incumbents receive .66 less percentage points of vote share for each term of seniority relative to majority-party members, and this difference is significant at the .01 level.

Column (11) shows that, in the Strong Party Era, majority and minority-party members receive the same return to seniority, a return that is much lower than the majority party's return in the Weak Party Era. These results suggest, consistent with our story, that seniority in the WPE is a defining characteristic for senior majority-party incumbents, a characteristic that differentiates them from both junior members of the majority party and members of the minority party. In the $\mathrm{SPE}$, in contrast, the strength of the party reduces the salience of seniority, lowering the return to seniority for majority-party incumbents and making the returns to seniority in the majority party

\footnotetext{
${ }^{15}$ Because we are already interacting seniority with minority, we felt it was easier to interpret these results by splitting the sample (into WPE and SPE), rather than by using a three-way interaction term. Results for the three-way interaction are substantively consistent with this strategy.
} 
and the minority party converge.

\section{Further Robustness Checks}

In this section we show that our results are robust to a variety of additional perturbations of the model and the data.

Because the precise year when the reforms of the 1970s started mattering is not pinned down, we test our model using different cut points between the Weak and Strong Party Eras. In Table 6, we

report estimates for $\hat{\beta}_{S P E}$ using five different definitions for the boundary between the Weak Party Era and the Strong Party Era and all three models (OLS, Fixed Effects, OLS with Uncontested).

\begin{tabular}{|r|ccccc|}
\hline \multicolumn{7}{|c|}{\begin{tabular}{c} 
Robustness of The Finding: \\
Measuring $\hat{\beta}_{S P E}$ in Different Specifications \\
\hline \\
\end{tabular} Model } & 1972 & 1974 & 1976 & 1978 & 1980 \\
\hline OLS & -.68 & -.64 & -.61 & -.58 & -.55 \\
& $(.12)$ & $(.12)$ & $(.11)$ & $(.11)$ & $(.11)$ \\
Fixed Effects & -.78 & -.77 & -.65 & -.52 & -.48 \\
& $(.13)$ & $(.12)$ & $(.12)$ & $(.11)$ & $(.11)$ \\
OLS with Uncontested & -1.04 & -1.01 & -1.01 & -.91 & -.83 \\
& $(.15)$ & $(.15)$ & $(.15)$ & $(.14)$ & $(.14)$ \\
\hline
\end{tabular}

Table 6 - In this Table we summarize our estimates for $\hat{\beta}_{S P E}$, the reduction in the return to seniority in the Strong Party Era. Across the columns, we use different cutoff years for our definition of the Weak and Strong Party Eras. In the first row we use our normal OLS specification. In the second row, we add fixed effects for individual representatives. In the third row, we repeat the OLS including uncontested elections, in which $100 \%$ of the vote share is attributed to the incumbent. In all cases, we cluster by representative.

The results show that the estimate is robust to the definition of the eras. Using different era definitions and three different specifications, we continue to find an estimate of $\hat{\beta}_{S P E}$ close to our main estimate, which found an average decrease in the return to seniority in the SPE of -.61 percentage points in majority-party incumbent vote share. As the columns of Table 6 show, our finding is not the result of one or two idiosyncratic years in the 1970s that need to be kept to one side of the boundary or the other.

The table shows that our results become more negative as we move the cutoff back in time. It is tempting to revise our definition of the Strong Party Era in light of this fact. Crook and 
Hibbing (1985) suggests using 1970 as the cutoff in a similar analysis, arguing that the reforms of the mid-70s were already anticipated by 1970 in Washington DC. ${ }^{16}$ This definition of the end of the WPE in fact generates the strongest possible result for our specification (moving any farther back before 1970 begins to attenuate the result). However, we believe it is prudent to continue to use 1976. This is a more conservative cutoff which keeps the Watergate election in the WPE, biasing us against finding a result.

To test whether our cutoff is particularly meaningful, we carry out a Monte Carlo permutations test. We randomly sample 16 years of our data to assign to a "placebo" WPE, and assign the remaining 16 to a simulated "SPE." Using these new era assignments, we re-run our main specification (column 1 in Table 1) and store the coefficients. We repeat this procedure 10,000 times. We find that Table 1's estimate for $\hat{\alpha}_{S P E}, 5.51$, is larger than over $99 \%$ of the estimates from the permutation test. Likewise, we find that our estimate for $\hat{\beta}_{S P E},-.61$, is smaller than over $99 \%$ of the simulated values. The histograms in Figure 4 display these findings graphically. In each histogram, the small region shaded in black represents simulated values more extreme than those estimated in our regressions. Both black regions contain less than 1 percent of the simulated density. The test suggests that the era division we have proposed is meaningful, and that the differences we find between the two eras are not replicable under a large number of other ways to split the data.

\footnotetext{
${ }^{16}$ This cutoff is perhaps more reasonable in the case of Crook and Hibbing (1985) because it is a story about the behavior of representatives and not voters. The former might reasonably be expected to anticipate reform earlier than the latter.
} 
Monte Carlo Permutations for $\hat{\alpha}_{S P E}$

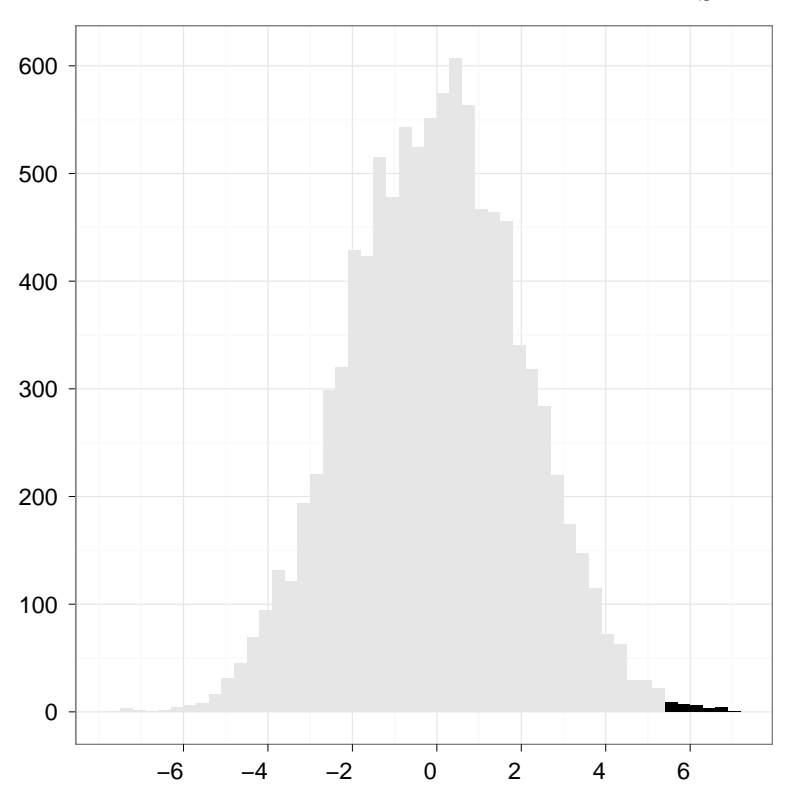

Monte Carlo Permutations for $\hat{\beta}_{S P E}$

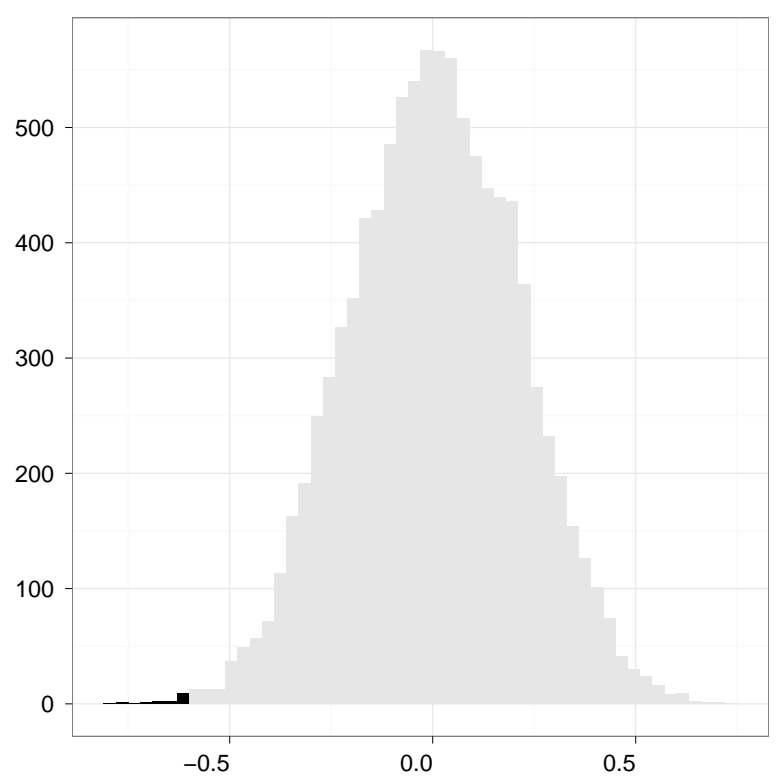

Figure 4 - Above are histograms from the simulations for the SPE intercept $\left(\hat{\alpha}_{S P E}\right)$ and for the SPE change in the return to seniority $\left(\hat{\beta}_{S P E}\right)$. The simulations come from Monte Carlo permutations tests in which years are randomly assigned to the WPE and SPE, respectively. The regions shaded in black show the simulations producing values more extreme than those found in our main specification. More than $99 \%$ of simulated coefficients are in the gray area, i.e. less extreme than our estimates. 
Our results are also robust to the following:

- Minor Candidates. Including all candidates, instead of simply using two-party vote share, does not affect our results.

- Logging seniority. Repeating the analysis using $\log$ (Seniority) does not affect the results.

- Uncontested elections. We can include uncontested elections by attributing $100 \%$ vote share to the incumbent in these cases. Doing so does not affect our results.

Finally, our results are robust to the inclusion of a variable measuring economic conditions. In Table 7, we control for the growth rate of per capita real disposable personal income, averaged over the past seven quarters of the congressional term, as used in Hibbs (2010). A large body of scholarship shows that voters hold members of the president's party accountable for the economy's performance (e.g. Kramer 1971, Fair 1978). We therefore interact the measure of Hibbs (2010) with a dummy indicating party match with the president. Formally, in column (12) we have:

$$
Y_{i}=\alpha+\alpha_{S P E} S P E_{i t}+\alpha_{P M} P M_{i t}+\beta_{S} S_{i t}+\beta_{S P E}\left(S_{i t} \cdot S P E_{i t}\right)+\beta_{I} I_{i t}+\beta_{P M I}\left(P M_{i t} \cdot I_{i t}\right)+\epsilon_{i t}
$$

Here $I$ is the average growth rate of per capita real disposable personal income over the previous seven quarters and $P M$ is a dummy indicating party match with the president. $\beta_{P M I}$ represents the additional vote share associated with economic growth for members of the same party as the president, benchmarked against members of the opposing party (whose return on economic growth is represented by $\beta_{I}$ ). In column (13), we add fixed effects for individual representatives.

As expected, we find a positive coefficient on $\hat{\beta}_{P M I}$, the interaction of Party Match and Average Income Growth, confirming the previous findings in the literature. More importantly, the inclusion of this variable does not affect our result, which remains significant with more than $99 \%$ confidence. In effect, all majority party members gain a premium in the Strong Party Era, but senior members, while still better off than junior members, are less better off than in the Weak Party Era. Seniority is not as valuable. 


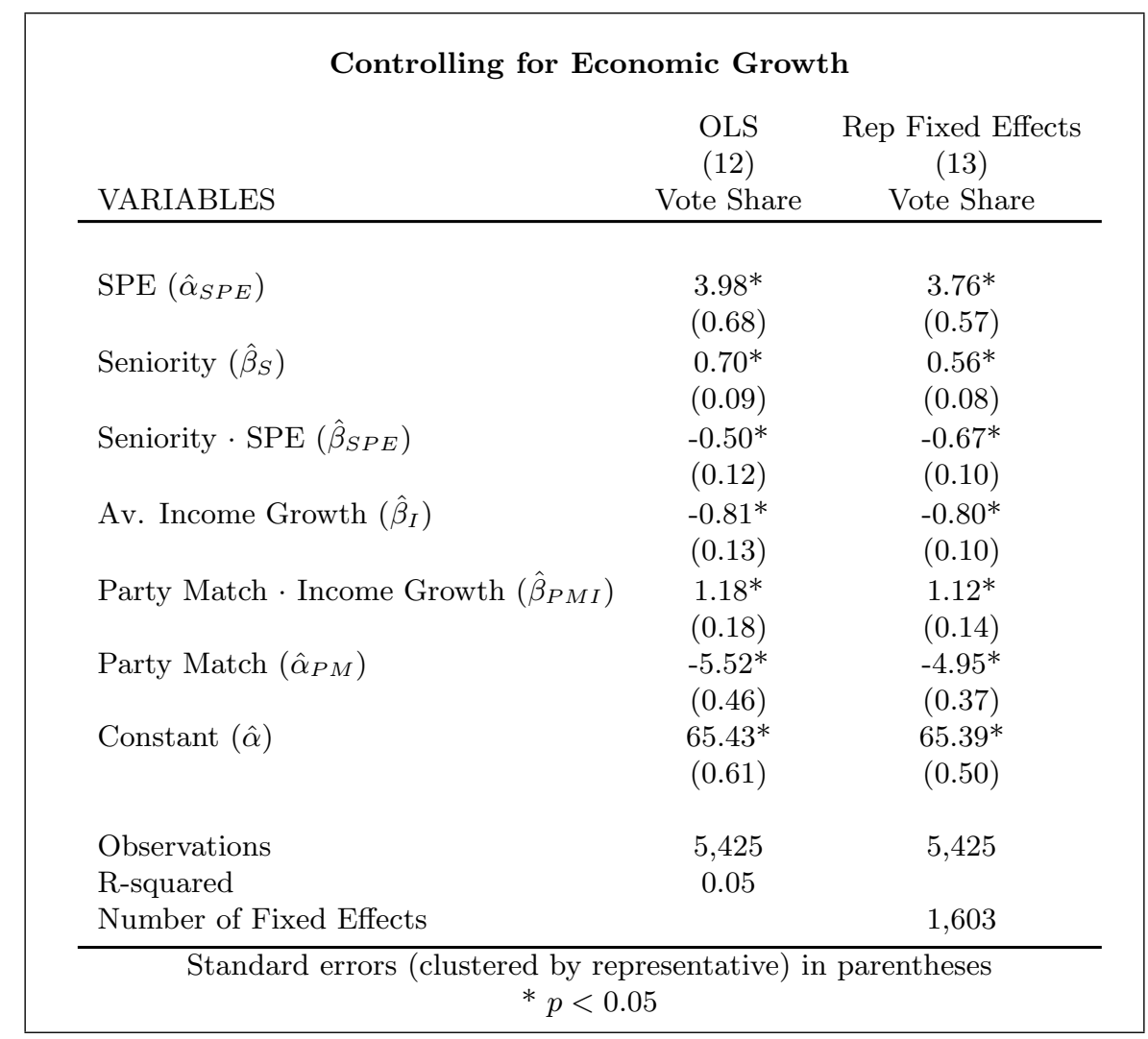

Table 7 - In this table we show that our results are robust to the inclusion of a measure of economic growth over the past congressional term. In column (12) we use our baseline OLS model, and in column (13) we use fixed effects for individual representatives. The results confirm the well-known result that economic growth helps candidates in the president's party $\left(\hat{\beta}_{P M I}\right)$ while showing that $\hat{\beta}_{S P E}$ remains negative and statistically significant.

\section{Discussion}

In the present paper we have sought to link two literatures - on congressional elections and legislative organization. Most analyses of congressional elections, whether for forecasting or explanatory purposes, tend to focus on election-specific features of the political environment (state of the economy, presidential popularity, etc.) and ignore institutional conditions. Most analyses of legislative organization, on the other hand, tend to stop at the boundaries of the legislature. ${ }^{17}$ We have demonstrated a link between the two arenas. Legislative organization, as Mayhew reminded us nearly forty years ago, has an electoral connection. For incumbents running for reelection, the electoral value of both the party label and their own member-specific characteristics is affected by the ways in which parties organize their legislative affairs.

\footnotetext{
$\overline{{ }^{17} \text { But see Brady, Fiorina, and Wilkins (2011). }}$
} 
We contrast two modes of legislative organization - the weak-party arrangement that typified mid-twentieth century congresses (1946-1976) and the strong-party arrangement that emerged in the last quarter of the twentieth century and has continued on into the twenty-first (1977-2008). Taking our cue from models of conditional party government (CPG), we adopted the view that homogeneity of policy preferences among members of the majority party induces them to organize the legislature in order to prosecute its agenda of commonly shared policy goals. This is accomplished by ceding power and resources to legislative party leaders, particularly the power to organize the legislative agenda and otherwise shape agenda setting. The CPG approach argues that, in facilitating the passage of policies consensually preferred by majority-party members, the party label becomes a more highly valued asset in subsequent elections.

Our results are consistent with this expectation, but with an important proviso. As implied by the CPG argument, there is a large and statistically significant boost in the vote shares of majority-party incumbents in the Strong Party Era. We estimated, from equation (1), a vote-share premium of $5 \%$ to $6 \%$. This is enjoyed by all members of the majority party. However, strong party organization is not pure profit for majority party members, even when they share a policy consensus. It comes at a cost, a cost rising with seniority as given by $\hat{\beta}_{S P E}=-.61$. This must be netted out. Senior members pay a price for centralizing agenda power in the party leadership - party leaders acquire authority and resources that formerly were commanded by seniors through the operation of seniority in the decentralized committee system.

This finding revises the standard CPG model in an important way. The benefits of a burnished party label redound to all party members. But the loss of a member's independent authority from ceding power to party leaders falls differentially on party members, viz., mainly on more senior members. Thus, the "condition" of conditional party government-preference homogeneity among party members - is no more than a necessary condition. Sufficiency requires that there be enough non-seniors willing to support trading off senior discretionary power in exchange for a burnished party label. Because the cost of lost influence must be netted out from the benefits of a burnished party label, there must be a "coalition of the willing" in the majority party prepared to empower party leaders. We expect the case for conditional party government is strongest after a homogenizing election in which the majority party is heavily endowed with junior legislators. 1974 
and 1994 suggest themselves as cases strongly satisfying these conditions. ${ }^{18}$

Our main result, as previous sections revealed, is quite robust. In a number of specifications we continue to find a "seniority tax" associated with the strong party era. A further embellishment of CPG theory is the effect of conditional party government on members of the minority party, something on which the existing CPG theory has little to say. As Table 5 shows, minority party members in the weak party era were not as well rewarded for accruing seniority as were majority party members, but they also have not borne a seniority tax in the strong party era. The tradeoff between concentrating agenda power (beneficial to majority party members) and reducing the agenda power associated with seniority (a tax on seniors in the majority party) is strictly a majority party affair.

While the effects we have documented are not the foremost factors in understanding, explaining, or forecasting congressional elections - electoral conditions just before an election, both national and local, remain of paramount importance - they are not trivial either. The accumulation of seniority, on the one hand, is clearly associated with increased vote share; and, on the other hand, the tax on this benefit for majority party members in periods of strong party leadership is highly significant as well. We believe these results should encourage students of congressional elections to take these endogenous legislative features on board in their attempts to explain electoral results, and students of congressional organization to backward induct from anticipated election effects to prior choices about legislative organization.

\footnotetext{
${ }^{18}$ One might think 2010 qualifies as well. But we are not convinced that the majority party of the 112 th Congress is homogeneous in the sense required by the CPG theory. The Main Street/Wall Street/Tea Party divide seems profound enough to undermine unified majority party preferences for strong legislative leadership. David Warsh, for example, writes: "The leading Tea Party figures in the House - Representatives Eric Cantor (R-Va.), Kevin McCarthy (R-Calif.) and Paul Ryan (R-Wis.), together with their allies among lobbyists, religious evangelists, editorialists and talk-show hosts - have fashioned a machine capable of bringing to bear enormous force on the Republican leadership on a moments notice."
} 


\section{References}

Aldrich, J.H., and D.W. Rohde. 2001. "The Logic of Conditional Party Government: Revisiting the Electoral Connection." In Congress Reconsidered. 7 ed. CQ Press, pp. 269-92.

Aldrich, J.H., D.W. Rohde, and M.W. Tofias. 2007. One D is Not Enough: Measuring Conditional Party Government, 1887-2002. In Party, Process, and Policy Making: Further New Perspectives on the History of Congress., ed. David Brady, and Mathew D. McCubbins. Stanford University Press, pp. 102-113.

Aldrich, J.H., M.M. Berger, and D.W. Rohde. 2002. The Historical Variability in Conditional Party Government, 1877-1994. In Party, Process, and Political Change in Congress. Stanford University Press, pp. 17-35.

Alford, J.R., and J.R. Hibbing. 1981. "Increased Incumbency Advantage in the House." Journal of Politics 43(4): 1042-61.

Ansolabehere, S., J.M. Hansen, S. Hirano, and J.M. Snyder. 2010. "More Democracy: The Direct Primary and Competition in US Elections." Studies in American Political Development 24(02): 190-205.

Brady, D.W., M.P. Fiorina, and A.S. Wilkins. 2011. "The 2010 Elections: Why Did Political Science Forecasts Go Awry?" PS: Political Science 6 Politics 44(02): 247-250.

Cox, G.W., and M.D. McCubbins. 2005. Setting the Agenda: Responsible Party Government in the US House of Representatives. Cambridge University Press.

Cox, G.W., and M.D. McCubbins. 2007. Legislative Leviathan: Party Government in the House. Cambridge University Press.

Crook, S.B., and J.R. Hibbing. 1985. "Congressional Reform and Party Discipline: The Effects of Changes in the Seniority System on Party Loyalty in the US House of Representatives." British Journal of Political Science 15(2): 207-26.

Fair, R.C. 1978. "The Effect of Economic Events on Votes for President." The Review of Economics and Statistics 60(2): 159-173.

Fiorina, M.P. 1977, 1989. Congress, Keystone of the Washington Establishment. Yale University Press.

Gelman, A., and G. King. 1990. "Estimating Incumbency Advantage Without Bias." American Journal of Political Science 34(4): 1142-1164.

Hastie, T.J., and R.J. Tibshirani. 1990. Generalized Additive Models. Chapman \& Hall.

Hibbs Jr, D.A. 2010. "The 2010 Midterm Election for the US House of Representatives." CEFOS Working Paper 9. http://www.douglas-hibbs.com/house2010election22september2010.pdf, (accessed September 2011).

Hirano, S., J.M. Snyder, S. Ansolabehere, and J.M. Hansen. 2010. "Primary Elections and Partisan Polarization in the US Congress." Quarterly Journal of Political Science 5(2): 169-191.

Jacobson, G.C. 1989. "Strategic politicians and the Dynamics of US House elections, 1946-86." The American Political Science Review 83(3): 773-793. 
Kramer, G.H. 1971. "Short-term Fluctuations in US Voting Behavior, 1896-1964." The American Political Science Review 65(1): 131-143.

Krehbiel, K. 1993. "Where's the Party?" British Journal of Political Science 23(2): 235-266.

Mayhew, D.R. 1974, 2004. Congress: The Electoral Connection. Vol. 26 Yale University Press.

McCarty, N.M., K.T. Poole, and H. Rosenthal. 2006. Polarized America: The Dance of Ideology and Unequal Riches. MIT Press Cambridge, MA.

McKelvey, R.D., and R. Riezman. 1992. "Seniority in Legislatures." American Political Science Review 86(4): 951-965.

Ornstein, Norman J., Robert L. Peabody, and David W. Rohde. 1977. "The Changing Senate: From the 1950s to the 1970s." In Congress Reconsidered. Praeger Publishers, pp. 3-21.

Remini, R.V. 2006. The House. New York, NY: Smithsonian.

Shaw, M. 1981. "Congress in the 1970s: A Decade of Reform." Parliamentary Affairs 34(3): 272-290.

Stonecash, J.M. 2011. "Democrats in Split-Outcome Districts and the 2010 Elections." PS: Political Science $\&$ Politics 44(02): 321-324.

Warsh, David. 2011. "Obama Smartens Up." http://www.economicprincipals.com (September 3, 2011). 